\title{
Relationships among Brand Experience, Brand Personality, And Customer Experiential Value
}

\author{
Ching-Jui Keng \\ National Taipei University of Technology \\ E-Mail: keng.chingjui@gmail.com \\ Van- Dat Tran \\ National Taipei University of Technology \\ E-Mail: dat2209@gmail.com \\ Tuyet Mai Le Thi \\ National Taipei University of Technology \\ E-Mail: tuyetmaimt@gmail.com
}

\begin{abstract}
The purpose of this study is to evaluate the relationships among brand experience, brand personality, and customer experiential value. Understanding these relationships is helpful to managers in their assessment of the level of appeal that will influence target consumers' perception of brand personality, as well as their brand experience. An empirical survey conducted with 270 real consumers in Taiwan is used to test the hypotheses. Data are analyzed using Amos 17 to understand the effect of the research model. The empirical results reveal that brand experience positively influenced customer value, brand personality positively affected customer experiential value, and brand experience positively affected brand personality.
\end{abstract}

Keywords: Brand Experience, Brand Personality, Customer Experiential Value 


\section{INTRODUCTION}

Today's marketplace has undergone a substantial change; we have gone from selling and promoting products and services to selling and enticing customers via experiences (Joy \& Sherry, 2003). This change can be attributed to the number of available products from which consumers can choose, which has increased tremendously, and consumers spending more time in making purchasing decisions (Ekstrom, 2010). Reimann et al. (2010) stated that when customers have begun to feel content that their basic needs are fulfilled, this contentment creates the necessity of fully understanding what affects customers throughout their purchasing process. Many companies throughout this world that is crowded with brands are competing for customers' attention; thus, it has become important to create a brand experience. A brand-related stimulus evokes "sensations, feelings, cognitions and behavioral responses" (Brakus et al., 2009).

We chose to study this topic for two reasons. The first is the gap in the research described in the literature on customer value. For example, Wu and Liang (2009) analyzed the effect of experiential value on customer satisfaction with service encounters in luxury hotel restaurants. Shieh and Cheng (2007) conducted several studies on the relationship between user experience and satisfaction. Keng et al. (2007) examined the relationships among service encounters, customer experiential value, and behavioral intention. Mathwick et al. (2001) investigated the effect of environmental design on experiential value (including consumer return on investment, service excellence, playfulness, and aesthetics). However, none of the existing research has evaluated the relationship among brand experience, brand personality, and customer value. Second, this issue is important to managers because it is precisely this level of effect that influences target consumers' purchase decisions and purchase intentions and helps to sustain the brand's perceived personality and brand experience between promotional cycles. This study validates a measure for assessing consumer value that is affected directly by brand experience and indirectly through brand personality.

Kotler and Armstrong's (2010) also defined marketing as a social and managerial process by which individuals and groups obtain what they need and want by creating and exchanging value with others. Therefore, customer value provides the foundation for all marketing activity and deserves the attention of every consumer researcher. This study's objective was to investigate the effects of brand experience, brand personality, and customer value when consumers purchase a product. The goal was to identify what customers feel and get from the brand experience and brand personality, 
as follows:

1. Understand the relationship between brand experience and customer experiential value.

2. Understand the relationship between brand personality and customer experiential value.

3. Understand the relationship between brand experience and brand personality.

\section{LITERATURE REVIEW}

\section{Brand Personality}

Brand personality has been defined as "a set of human characteristics associated to a brand" (Aaker, 1997). Researchers have discovered that brand personality helps a consumer to reveal his/herself (Belk, 1988), an ideal self (Malhotra, 1988), or exact aspects of the self (Kleine et al., 1993) through use of a brand. In addition, Aaker (1997) noted that consumers perceive that brands have five distinct personality dimensions: sincerity (domestic, honest, genuine, and cheerful), excitement (daring, spirited, imaginative, up-to-date), competence (reliable, responsible, dependable, efficient), sophistication (glamorous, pretentious, charming, romantic), and ruggedness (tough, strong, outdoorsy, rugged).

Based on this definition and the dimensions of brand personality, several studies have examined this construct. Brands are widely acknowledged to have anthropomorphic characteristics that ascribe specific human-like personality traits; research has suggested that consumers select brands that are congruent with their needs and personality characteristics. Brand personality traits are formed from consumer experience and any direct/indirect contact between consumers and the brand (Aaker, 1997; Berry, 2000; Keller, 1993). By understanding the degree of appeal of a brand's personality, managers can better understand the relevance, potency, and endurance of a particular brand personality and how this personality influences purchase intentions and behaviors (Freling, Crosno, \& Henard, 2011). In addition, Maehle, Otnes, and Supphellen (2011) indicated that specific brand personality dimensions are associated with particular product categories. However, brands mentioned as strong on specific personality dimensions share commonalities beyond just a product category. For instance, brands that are perceived as sincere share family-related associations and high morals, brands considered exciting offer consumers an opportunity to experience feelings of excitement related to special 'exciting' occasions, brands thought of as competent are mostly associated with expertise and quality, and brands considered sophisticated usually have a feminine 
nature, whereas brands associated with ruggedness have a masculine nature. In this section, this study discusses a key concept, the brand personality dimension scale. A brand personality can help create a self-expression benefit that becomes a vehicle through which the customer can express his or her own personality.

\section{Brand Experience}

Experiences are private events that occur in response to stimulation; they often result from direct observation and/or participation in events, whether real, virtual, or in dreams (Schmitt, 1999). The experience states may be categorized into rational activities (cognitive), emotional responses (affective), and behavioral intentions (conation) (Hirschaman \& Holbrook, 1982; Padgett \& Allen, 1997). According to Schmitt (1999), sense marketing appeals to the senses; feel marketing appeals to the inner feelings and emotions of consumers; think marketing appeals to consumer creativity; the act experience appeals to bodily experience, lifestyle, and interactions of consumers; and relationship marketing appeals to other people or cultures. Brand experience was conceptualized as a subjective, internal consumer response (sensation, feeling, cognition) and a behavioral response evoked by brand-related stimuli (e.g., colors, shapes, typefaces, designs, slogans, mascots, brand characters) that are part of a brand's design and identity, packaging, communications, and environments (Brakas et al., 2009). He also noted that there is no one-to-one correspondence, such that a certain stimulus type would generate a certain experience dimension and only that dimension.

Several researchers have studied the brand experience based on its definition and dimensions. For example, Hulten (2011) investigated whether firms should apply sensorial strategies that allow them to differentiate and position a brand in the human mind as an image. Brand experience should affect not only past-directed satisfaction judgments but also future-directed consumer loyalty. A greater brand experience not only is associated with familiarity, but also critically affects understanding, enjoying, enhancing, and fostering the brand. In addition, Xu et al. (2011) showed that the brand experience can be positively but indirectly associated with relational benefits and that brand familiarity, brand image, and brand personality can serve as mediators in the brand experience. This finding suggests that practitioners should understand customers' perceptions of relational benefits and develop marketing strategies that will result in ongoing relationships with consumers.

\section{Customer Experiential Value}


Woodall (2003, p. 2) defined value as the "personal perception of advantage arising out of customer association with the offerings of an organization." According to Holbrook and Corfman (1985), the consumption experience itself can also be rich in value. Experiential value perceptions are based on interactions involving either direct usage or distanced appreciation of goods and services. These interactions provide the basis for the relativistic preferences held by the individuals concerned.

Empirical issues await investigation in customer value research. To understand the categories or dimensions on which such assessments are based and to create a customer value framework that captures the domain of the construct in a high-ranking paper on customer value, Zeithaml (1988) explored the concepts of perceived price, perceived quality, and perceived value. She investigated whether customers thought of value in four ways: value is low price, value is whatever I want in a product, value is the quality I get for the price I pay, and value is what I get for what I give.

According to Mathwick et al. (2001), consumers today are looking for value, choice, and a great customer experience. Market trends also show that the role of customer experiential value has attracted growing attention among practitioners. Holbrook (1994) broadened the traditional conceptualization of experiential value to incorporate three spheres: extrinsic versus intrinsic value, active versus reactive value, and self- versus other-oriented value. Based on the definition and the values of the dimensions of experience, several studies have examined how variables are related. Researchers have reported that customer value is typically built on experiential perception and is the result of direct or indirect interaction during the consumption process (Holbrook, 1994, 2000; Mathwick et al., 2001). Based on this research, the value landscape can be divided into four quadrants framed by intrinsic/extrinsic sources of value on one axis and active/reactive value on the other. The four dimensions of experiential value are as follows: consumer return on investment, service excellence, playfulness, and aesthetic appeal.

\section{RESEARCH METHOD}

\section{Research Hypotheses}

Following Hoch (2002), experience does not occur only when consumers search for products, when they shop for them and receive service, and when they consume them. Experience can also occur indirectly (e.g., when consumers are exposed to advertising and marketing communications). Barkus et al. (2009) conceptualized brand experiences as subjective, internal consumer responses (sensations, feelings, 
and cognitions) and behavioral responses evoked by brand-related stimuli that are part of a brand's design and identity, packaging, communications, and environments. As Barkus et al. (2008) claimed, experience provides value and utility similar to effective attributes. Thus, we expect that the more a brand evokes multiple experience dimensions, and the higher the overall score on the scale, the more satisfied a consumer will be with the brand. That would lead to pleasurable outcomes and therefore we would expect consumers to want to repeat the experience. A positive brand experience affects not only past-directed satisfaction judgments but also future-directed consumer loyalty. With a positive experience, consumers should be more likely to buy a brand again and recommend it to others and less likely to buy an alternative brand (Mittal \& Kamukura, 2001; Oliver, 1997). Therefore, we expect that the more a brand evokes multiple experience dimensions, the higher will be the customer experiential value with the brand. Thus:

H1: Brand experience has a positive impact on customer experiential value.

According to Aaker (1997), a brand's personality may be inferred from people associated with the brand (e.g., users, company representatives, endorsers), product attributes, category associations, brand name, and communications. A useful input in this inference is likely to be brand experience. The higher the overall score on the brand experience scale, the more likely the consumer will be to endow the brand with personality associations. Aaker (1996) noted that the brand may be viewed as a person that is competent, trustworthy, active, or youthful. A brand personality may help communicate a product's attributes and thus contribute to a functional benefit. Similarly, it can help create a self-expression benefit that becomes a vehicle through which the customer expresses his or her own personality. Following Aaker et al. (2004), it is widely acknowledged that brands have anthropomorphic characteristics that ascribe specific human-like personality traits and research has suggested that consumers select brands that are congruent with their needs and personality characteristics. Therefore, the more a brand is associated with human characteristics, the more a consumer will appreciate it.

$\mathrm{H} 2$ : Brand personality has a positive effect on customers' experiential value.

Joha, Sengupta, and Aaker (2005) claimed that both brand experience and judgment of a brand's personality occur in response to brand contact and include a categorization process; however, the formation and updating of brand personality is highly inferential. A brand's personality is inferred from people associated with the brand (e.g., users, company representatives, endorsers), product attributes, category associations, brand name, and communications. The most important aspect of a 
brand's personality is brand experience (Aaker, 1997). Maehle, Celeotnes, and Supphellen (2011) noted that specific brand personality dimensions are associated with particular product categories. However, brands mentioned as strong on respective personality dimensions share commonalities beyond just a product category. Moreover, brands that consumers perceive as lacking on a particular personality dimension also share common attributes. In addition, a trait judgment about a brand's sincerity, excitement, competence, sophistication, or ruggedness can be facilitated when the consumer attends to specific sensory, affective, intellectual, or behavioral aspects.

H3: Brand experience has a positive effect on brand personality.

\section{Sampling and Data Collection}

Based on the literature review, we selected or constructed items to refer to brand experience, brand personality, and customer experiential value. This study measured the effect of brand experience and brand personality on customer experiential value. To ensure external validity and generalizability of the direct effects of brand experience on customer experiential value and the indirect effects mediated by brand personality, information was collected from real consumers. Two hundred seventy questionnaires were distributed to consumers through a posting on Facebook. We received responses from 120 males and 150 females in the age range of 14 to 50 years old. Of the 270 responses, 258 were usable, resulting in a 95.55 percent response rate, which is sufficient for a survey of this type.

Data were analyzed using Amos 17 to investigate the effects of the entire model. The questionnaire items used a 7-point Likert-type scale, ranging from (1) strongly disagree to (7) strongly agree.

\section{DATA ANALYSIS AND RESULT}

\section{Confirmatory Factor Analysis}

The goodness of fit for the model was assessed by examining the chi-squared statistic and the comparative fit index (CFI). The Goodness-of-Fit Index (GFI) measures the fitness of one model versus another (Hair et al., 2006), the Normed Fit Index (NFI) measures the proportion by which a model is improved in terms of fit compared to the base model (Hair et al., 2006), and the root mean square error of approximation (RMSEA) provides information in terms of discrepancy per degree of freedom for a model (Steiger, 1990). The accepted thresholds for these indexes is the $\chi 2$ df ratio, which should be less than 3 ; the values of GFI, NFI, CFI, and Incremental 
Fit Index (IFI) should be greater than 0.9; and RMSEA is recommended to be up to 0.05 and is acceptable up to 0.08 (Gefen et al., 2005).

\section{Result of Confirmatory Factor Analysis}

We ran a confirmatory factor analysis (CFA) on the measurement model consisting of the brand experience, brand personality, and customer experiential value. The measurement model revealed an adequate model fit with the data $(\chi 2=131.557$, $\mathrm{df}=59, p<0.001 ; \chi 2 / \mathrm{df}=2.230 ; \mathrm{CFI}=0.953 ; \mathrm{GFI}=0.928 ; \mathrm{TLI}=0.938 ; \mathrm{IFI}=0.953$; $\mathrm{NFI}=0.918$; PNFI $=0.695$; PCFI $=0.721$, and RMSEA $=0.069)$. As shown in Table 1 , most of the model fit indexes exceed the respective common acceptance levels suggested by previous research, demonstrating that the measurement model exhibited a good fit with the data collected.

\section{Reliability of The Measurement Instrument}

De Villis (1991) considered a Cronbach's $\alpha$ greater than 0.7 as acceptable. The Cronbach's $\alpha$ in each of the variables was greater than 0.7 (see Table 1). Reliability was assessed in terms of composite reliability, which measures the degree to which items are free from random error and therefore yield consistent results. Composite reliabilities in our measurement model ranged from 0.83 to 0.84 (see Table 1), above the recommended cutoff of 0.70 (Fornell \& Larcker, 1981; Nunnally \& Bernstein, 1994). The average variance extracted (AVE) for all the factors was greater than or equal to 0.5, which is acceptable (Fornell \& Larcker, 1981).

\section{Construct Validity}

Construct validity is the extent to which a set of measured variables actually reflects the latent construct they are designed to measure (Hair et al., 2006). Construct validity is set in this study by establishing face validity, convergent validity, and discriminant validity.

Adopting the measurement items used in the study from the existing literature and adapting them to the present research context established face validity.

Examining the factor loadings assessed convergent validity and AVE of the constructs, as Fornell and Larcker (1981) suggested. All the indicators had significant loadings on the respective latent constructs $(p<0.001)$ with values varying between 0.55 and 0.89 (see Table 1). In addition, the AVE for each construct was greater than or equal to 0.50 , which further supports the convergent validity of the constructs.

Discriminant validity was tested by comparing the AVE with the squared 
correlation between constructs (Fornell \& Larcker, 1981). The AVEs were greater than the squared correlations between any pair of constructs, meaning they exhibited discriminant validity. Thus, the measurement model demonstrated discriminate validity (see Table 2).

\section{Results of Structural Equation Model Testing}

$\mathrm{H} 1$ through $\mathrm{H} 3$ were examined with structural equation modeling (SEM) using AMOS 17.0. Results of the SEM indicate an adequate model fit with the data $\left(\mathrm{x}^{2}=\right.$ 103.545, $\mathrm{df}=57$, at $p<0.001$; $\mathrm{CFI}=0.970$; $\mathrm{TLI}=0.959$; $\mathrm{IFI}=0.970$; $\mathrm{RFI}=0.912$; NFI $=0.936$; and RMSEA $=0.056)$. The influence of brand experience on customer experiential value was significant ( $\mathrm{y}=0.423, p<0.001$ ), supporting H1. Finally, the influence of brand personality on customer experiential value was significant $(\mathrm{y}=$ $0.509 ; p<0.001$ ). Therefore, $\mathrm{H} 2$ was supported. The influence of brand experience on brand personality was also significant $(\mathrm{y}=0.419 ; p<0.001)$, supporting H3 (see Figure 1).

\section{CONCLUSIONS AND SUGGESTIONS}

The purpose of this research was to investigate the relationships among brand experience, brand personality, and customer value. To ensure the external validity and generalizability of the direct effects of brand experience on customer value and the indirect effects mediated by brand personality, information was collected from real consumers. Two hundred seventy questionnaires were distributed to consumers. The empirical results provide strong support for the importance of brand experience in influencing customers' experiential value and brand experience; all five dimensions of brand personality significantly influenced customer experiential value. The survey was hosted on Google, an online survey-hosting site, and was fielded in March 2012. Data were analyzed using AMOS 17 to understand the effects of the overall model.

The empirical results provide strong support for the importance of brand experience in influencing customer experiential value and brand experience; all five dimensions of brand personality significantly influenced customer experiential value. According to Table 1, the Cronbach's $\alpha$ for each of the variables was greater than 0.7 . Analysis of the composite reliability for each variable is as follows: value of 0.83 for brand experience, 0.83 for brand personality, and 0.83 for customer experience. Furthermore, according to Figure 1, H1 (relationship between brand experience and customer experience value) resulted in $\mathrm{y}=0.423, p<0.001^{* * *}$ and hypotheses $\mathrm{H} 2$ (relationship between brand personality and customer experiential value) in $y=0.509$; 
$p<0.001^{* * *}$. Thus, $\mathrm{H} 1$ and $\mathrm{H} 2$ received support. $\mathrm{H} 3$ (relationship between brand experience and brand personality) is $\mathrm{y}=0.419 ; p<0.001^{* * *}$ and was thus supported. Given the exploratory nature of the study, the validity and reliability of the scales and the items in the questionnaire were deemed adequate.

Table 1 Confirmatory factor analysis (CFA) fitting Indices

\begin{tabular}{|c|c|c|c|c|c|}
\hline Factor & $\begin{array}{l}\text { Factor } \\
\text { Loading }\end{array}$ & Cronbach' $\alpha$ & CR & $\mathrm{t}$-value & AVE \\
\hline Brand Personality & & 0.88 & 0.83 & & 0.506 \\
\hline Sincerity & 0.66 & & & 7.790 & \\
\hline Excitement & 0.76 & & & 8.321 & \\
\hline Competence & 0.86 & & & 8.610 & \\
\hline Sophistication & 0.69 & & & 7.790 & \\
\hline Ruggedness & 0.55 & & & & \\
\hline Brand Experience & & 0.80 & 0.84 & & 0.57 \\
\hline Sensory & 0.63 & & & 8.226 & \\
\hline Affective & 0.81 & & & 10.221 & \\
\hline Behavioral & 0.66 & & & 8.751 & \\
\hline Intellectual & 0.89 & & & & \\
\hline Customer experiential value & & 0.90 & 0.83 & & 0.56 \\
\hline Aesthetic & 0.80 & & & 13.652 & \\
\hline Playfulness & 0.76 & & & 13.352 & \\
\hline Service excellent & 0.56 & & & 10.849 & \\
\hline CROI & 0.84 & & & & \\
\hline
\end{tabular}


Table 2 Discriminant Validity

\begin{tabular}{llll}
\hline & Brand Experience & Brand Personality & Customer value \\
\hline Brand Experience & 0.506 & & \\
\hline Brand Personality & 0.116 & 0.57 & \\
\hline Customer value & 0.293 & 0.311 & 0.56 \\
\hline
\end{tabular}

Note: All correlations are significant at the 0.01 level (2-tailed). The diagonals represent the average variance extracted. The AVEs were greater than the squared correlations between any pair of constructs.

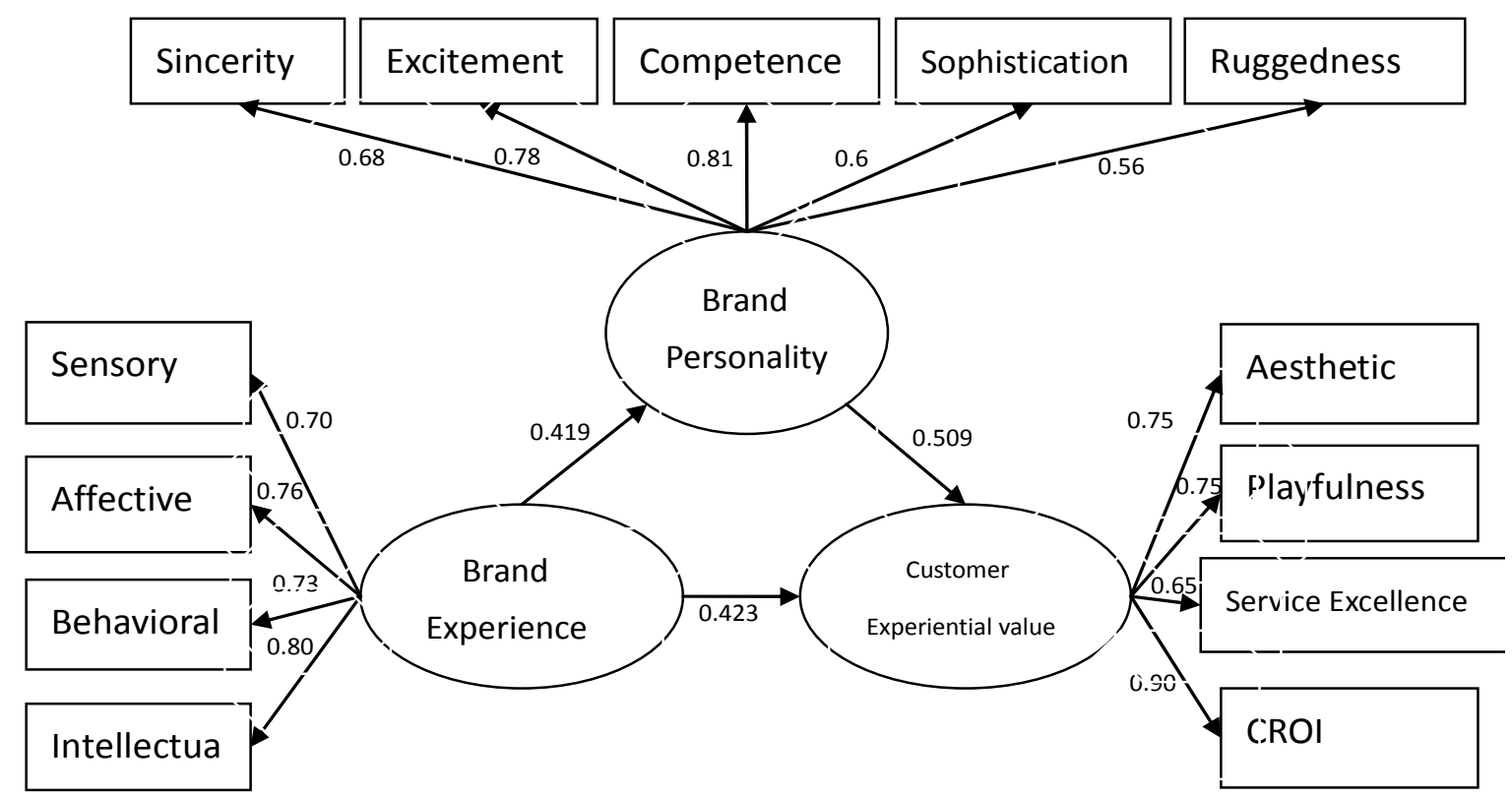

Figure 1 Hypotheses testing result

\section{Academic Implication}

This research included three sub-studies: the first to investigate the relationship between brand experience and customer experiential value, the second to investigate the relationship between brand personality and customer experiential value, and the third to investigate the relationship between brand experience and brand personality. These sub-studies help to identify how brand experience is directly affected by customer experiential value (aesthetics, playfulness, service excellence, customer return on investment) and indirectly affected through brand personality. The implication of the study for academic theory is that the brand experience is directly 
affected by customer experiential value and indirectly affected by brand personality.

\section{Managerial Implication}

This study will be useful not only in academic research but also in marketing practice. The relationships discussed here can help managers assess the level of appeal that will influence target consumers' perception of brand personality and brand experience. Essentially, this study proposes a model that addresses the following three basic issues: what defines brand experience, what defines brand personality, and what defines customer experiential value. Brakus et al. (2009) proposed a framework suggesting that brand experience has a behavioral impact, directly affecting consumer satisfaction and loyalty and indirectly affecting brand personality.

\section{Limitation and Further Research}

The objective of this study was to investigate whether there is a direct relationship between brand experience and customer experiential value or whether there is an indirect relationship via brand personality. This research did not measure whether brand experience has a positive or negative impact on customer experiential value. Thus, future research should investigate how positive and negative experiences affect customer behavior. In addition, online surveys depend on people to be honest about basic demographic information such as age, gender, and race. Since people are not always honest, this can create inaccuracy in the data. Surveys that are sent to individuals who have been prescreened will not suffer from the same degree of inaccuracy. Otherwise, further research should focus on the antecedents. For example, how exactly are brand experience dimensions evoked by brand-related stimuli? In addition, we have demonstrated the impact of brand experience, both directly and indirectly, on long-term and short-term consequences, such as customer experiential value that includes aesthetics, playfulness, service excellence, and customer return on investment. Future research should address whether brand experiences build customer equity and authenticity and how managers should market brands to create an experience that builds such authenticity and equity.

\section{REFERENCE}

Aaker, D. A. (1996). Measuring brand equity across products and markets. $\begin{array}{llll}\text { California } \quad \text { Management } & \text { Review, } & \text { (3), } & \text { 102-20. }\end{array}$ http://dx.doi.org/10.2307\%2F41165845 
Aaker, J., Fournier, S., \& Brasel, S. (2004). When good brands do bad. Journal of Consumer Research, 31(1), 1-16. http://dx.doi.org/10.1086\%2F383419

Aaker, J. (1997). Dimensions of brand personality. Journal of Marketing Research, 34

(3), 347-356. http://dx.doi.org/10.2139\%2Fssrn.945432

Belk, R. W. (1988). Possessions and the extended self. Journal of Consumer Research, 15(2), 139-168. http://dx.doi.org/10.1086\%2F209154

Berry, L. L. (2000). Cultivating service brand equity. Journal of Academy of Marketing Science, $\quad 28 \quad$ (1), 128-137. http://dx.doi.org/10.1177\%2F0092070300281012

Brakus, J. J., Schmitt, B. H., \& Zhang, S. (2008). Experiential attributes and consumer judgments. Northampton, MA: Edward Elgar.

Brakus, J. J., Schmitt, B. H., \& Zarantonello, L. (2009). Brand experience: What is it? How is it measured? Does it affect loyalty? Journal of Marketing, 73(3), 52-68. http://dx.doi.org/10.1509\%2Fjmkg.73.3.52

DeVillis, R. F. (1991). Scale development: Theory and applications. Newbury Park, CA: Sage.

Ekström, K. (2010). Consumer behaviour: A nordic perspecitve. Lund, Sweden: Studentlitteratur.

Ekström, K. (2010). Introduction. In Ekström, K. consumer behaviour: a nordic perspective. Lund, Sweden: Studentlitteratur.

Fornell, C., \& Larcker, D. F. (1981). Evaluating structural equation models with unobservable and measurement error. Journal of Marketing Research, 18(1), 39-50. http://dx.doi.org/10.2307\%2F3151312

Freling, T. H., Crosno, J. L., \& Henard, D. H. (2011). Brand personality appeal: conceptualization and empirical validation. Journal of the Academy of Marketing Science, 39 (3), 392-406. http://dx.doi.org/10.1007\%2Fs11747-010-0208-3

Gefen, D., \& Straub, D. W. (2005). A practical guide to factorial validity using PLS-graph: Tutorial and annotated example. Communications of the AIS, 16(5), 91-109, 2005.

Hair, J. F., Black, W. C., Babin, B. J., Anderson, R. E., \& Tatham, R. L. (2006). Multivariate data analysis ( $6^{\text {th }}$ ed.) Upper Saddle, NJ: Pearson Prentice Hall.

Hirschman, E. C., \& Holbrook, M. B. (1982). Hedonic consumption: Emerging concepts, methods, and propositions. Journal of Marketing, 46 (3), 92-101. http://dx.doi.org/10.2307\%2F1251707

Hoch,S. J. (2002). Product experience is seductive. Journal of Consumer Research, 29 (3), 448-54. http://dx.doi.org/10.1086\%2F344422 
Holbrook, M. B. (1994). Chapter 2: The Nature of customer value: An axiology of services in the consumption experience. In Roland T. Rust and Richard L. Oliver (Eds.). Service Quality: New Directions in Theory and Practice. (pp. 21-71). Newbury Park, CA: Sage Publications. http://dx.doi.org/ $10.4135 / 9781452229102$

Holbrook, M.B. (2000). The millennial consumer in the texts of our times: Experience and entertainment. Journal of Macromarketing, 20 (2), 178-92. http://dx.doi.org/10.1177\%2F0276146700202008

Holbrook, M. B., \& Corfman, K. (1985). Quality and value in the consumption experience: Phaedrus rides again. (pp. 31-51) Lexington, MA: Lexington Books.

Hultén, A. (2011). Sensory marketing: the multi-sensory brand-experience concept. European Business $\quad$ Review, $23 \quad$ (3), 256-273. http://dx.doi.org/10.1108/09555341111130245

Johar, G., Sengupta, J., \& Aaker, J. (2005). Two roads to updating brand personality Impressions: Trait versus Evaluative Inference. Journal of Marketing Research, 42 (4), 458-69.

Joy, A., \& Sherry, J. (2003). Speaking of art as embodied imagination: A multisensory approach to understanding aesthetic experience. Journal of Consumer Research, 30 (2), 259-282. http://dx.doi.org/10.1086\%2F376802

Keller, K. L. (1993). Conceptualizing, measuring, and managing customer-based brand equity. Journal of Marketing, 57 (1), 1-22. http://dx.doi.org/10.2307/1252054

Keng, J. C., Huang, T. L., \& Zheng, L. J. (2007). Modeling service encounters and customer experiential value in retailing. International Journal of Service Industry Management, 18 (4), 349-367. http://dx.doi.org/10.1108\%2F09564230710778137

Kleine, R, E., Kleine, S. S., \& Kernan, J. B. (1993). Mundane consumption and the self: A social-identity perspective. Journal of Consumer Psychology, 2(3), 209-235. http://dx.doi.org/10.1016/S1057-7408(08)80015-0

Kotler, P., \& Armstrong, G. (2010). Principles of Marketing (13 ${ }^{\text {th }}$ Ed.). Upper Saddle River, NJ: Pearson. Cannon, T. (1998). Marketing Principles and Practice $\left(5^{\text {th }}\right.$ Ed.). London, England: Casse.

Maehle, N., Celeotnes, O., \& Supphellen, M. (2011). Consumers' perceptions of the dimensions of brand personality. Journal of Consumer Behavior, 10 (5), 290-303. http://dx.doi.org/10.1002/cb.355 
Malhotra, N. K. (1988). Self-Concept and Product Choice: an Integrated Perspective. $\begin{array}{llllll}\text { Journal of Economic Psychology, } 9 & \text { (1), } & \text { 1-28. }\end{array}$ http://dx.doi.org/10.1016\%2F0167-4870\%2888\%2990029-3

Mathwick, C., Malhotra, N., \& Ridgon, E. (2001) Experiential value: conceptualization, measurement and application in the catalog and Internet shopping environment. Journal of Retailing, 77 (1), 39-56. http://dx.doi.org/10.1016\%2FS0022-4359\%2800\%2900045-2

Mittal, V., \& Kamakura, W. A. (2001). Satisfaction, repurchase intent, and repurchase behavior: Investigating the moderating effect of customer characteristics. Journal of Marketing Research, 38 (1), 131-42. http://dx.doi.org/10.1509\%2Fjmkr.38.1.131.18832

Nunnally, J. C., \& Bernstein, I. H. (1994). Psychometric theory ( $3^{\text {rd }}$ Ed.). New York, NY: McGraw Hill Inc.

Oliver, R. L. (1997). Satisfaction: A behavioral perspective on the consumer. Boston, MA: McGraw-Hill.

Padgett, D., \& Allen, D. (1997). Communicating experiences: A narrative approach to creating service brand image. Journal of Advertising, 26 (4), 49-62. http://dx.doi.org/10.1080\%2F00913367.1997.10673535

Reimann, M., Zaichkowsky, J., Neuhaus, C., Bender, T., \& Weber, B. (2010). Aesthetic package design: A behavioral, neural, and psychological investigation. Journal of Consumer Psychology, $20 \quad$ (4), 431-441. http://dx.doi.org/10.1016\%2Fj.jcps.2010.06.009

Schmitt, B. H. (1999). Experiential marketing: How to get customers to sense feel think act relate to your company and brands. New York, NY: The Free Press.

Shieh, K. F., \& Cheng, M. S. (2007). An empirical study of experiential value and lifestyle and their effects on satisfaction in adolescents: an example using online gaming. Adolescence, 42 (165), 199-215.

Steiger, J. H. (1990). Structural model evaluation and modification: An interval estimation approach. Multivariate Behavioral Research, 25(2), 173-180. http://dx.doi.org/10.1207\%2Fs15327906mbr2502_4

Woodall, T. (2003). Conceptualizing "value for the customer": An attribution, structural and dispositional analysis. Academy of Marketing Science Review, 12. Retrieved from www. am review.org/articles/woodall12-2003.pdf

Wu, C. H., \& Liang, R. D. (2009). Effect of experiential value on customer satisfaction with service encounters in luxury-hotel restaurants. International 
Journal of Hospitality Management, 28 (4), 586-593. http://dx.doi.org/10.1016\%2Fj.ijhm.2009.03.008

Xu, Y. Y., Zhang, M. L., \& Tang, S. T. (2011). The impact of brand experience on relational benefit: The role of brand familiarity, brand image and brand personality. Advanced materials research, 225, (10), 103-106. http://dx.doi.org/10.4028\%2Fwww.scientific.net\%2FAMR.225-226.103

Zeithaml, V. (1988). Consumer perceptions of price, quality, and value: Means-end model and synthesis of evidence. Journal of Marketing, 52 (3), 2-22. http://dx.doi.org/10.2307\%2F 1251446 